\title{
VISKOSITAS DARAH DAN ASPEK MEDISNYA
}

\author{
Lili Irawati \\ Bagian Fisika Kedokteran Fakultas Kedokteran Universitas Andalas \\ E-mail : lili.irawati@gmail.com
}

\begin{abstract}
Abstrak
Faktor-faktor yang mempengaruhi viskositas darah adalah: a) Hematokrit : hematokrit yang meningkat akan diikuti viskositas darah yang meningkat. b) Suhu tubuh: bila suhu tubuh naik, viskositas turun. c) Kadar protein plasma: bila kadarnya naik maka viskositas naik dan sebaliknya. d) Kecepatan aliran darah: bila kecepatan aliran darah turun maka viskositas naik. e) Diameter pembuluh darah: bila diameter pembuluh darah kurang dari 1,5 mm, maka efek viskus jauh lebih sedikit.

Aplikasi pada Hukum Poiseuille, menyatakan bahwa kecepatan aliran darah bergantung pada radius, ketika radius meningkat dua kali lipat maka kecepatan aliran darah meningkat menjadi 16 kali. Demikian juga ketika radius dibuat lebih kecil, kecepatan aliran menurun secara drastis seperti penebalan pada dinding arteri, akan menurunkan kecepatan aliran darah seperti pada angina pectoris, penyebab tersering adalah arteriosclerosis.
\end{abstract}

Kata kunci : Viskositas darah, Hukum Poiseuille

\section{Abstract}

The factors affecting the blood viscosity are following: a) Haematocrit: increased haematocrit will be followed increased the blood viscosity. b) The body temperature: inclined the body temperature, viscosity decline. c) Plasma protein levels: when it levels increase then viscosity also increase and conversely. d) The rate of the blood flow: when the rate down, the viscosity up. e) The vessel diameter (sizes): when the diameter less than $1,5 \mathrm{~mm}$, the viscous effect much less.

The application to Poiseulle's Law, suggest that the rate of blood depend on radius, once the radius increased twice then the rate of blood flow increased 16 times. Simiarly, once the radius is reduced, the rate of blood flow decrease dramaticaly such as the thickness on the artery vessel wall, will decrease the rate of blood flow such as angina pectoris, the most caused are arterioclerosis.

Key word: blood viscosity, Poiseulle's Law 


\section{Pendahuluan}

Di dalam tubuh manusia, darah mengalir keseluruh bagian (organorgan) tubuh secara terus-menerus untuk menjamin suplai oksigen dan zatzat nutrien lainnya agar organ-organ tubuh tetap dapat berfungsi dengan baik. Aliran darah keseluruh tubuh dapat berjalan berkat adanya pemompa utama yaitu jantung dan sistem pembuluh darah sebagai alat pengalir/distribusi. ${ }^{(1)}$

Pada orang dewasa, jumlah volume darah yang mengalir di dalam sistem sirkulasi mencapai 5-6 liter (4,7 - 5,7 liter). Darah terus berputar mengalir di dalam sistem sirkulasi sistemik dan paru-paru tanpa henti.

Darah merupakan cairan yang terdiri dari plasma (cairan bening) dan selsel darah (yang terdiri dari eritrosit, leukosit dan trombosit). Adanya sel-sel darah menyebabkan adanya semacam pergeseran intern (internal friction) diantara lapisan yang berdampingan sehingga menyebabkan adanya sifat viskositas/kekentalan darah. ${ }^{(1)}$

\section{Aliran Darah Dalam Pembuluh a. Aliran Darah Laminar}

Bila darah mengalir dengan kecepatan tetap melalui pembuluh darah yang panjang dan licin, darah mengalir dalam aliran laminar, dengan setiap lapisan darah tetap berjarak sama dari dinding. Demikian pula, bagian sentral dari darah berada dibagian tengah pembuluh. Tipe aliran ini disebut aliran laminar atau aliran streamline, dan aliran ini berlawanan dengan aliran turbulen, di mana darah mengalir ke semua arah dalam pembuluh dan secara kontiniu tercampur di dalam pembuluh. $^{(2-4)}$

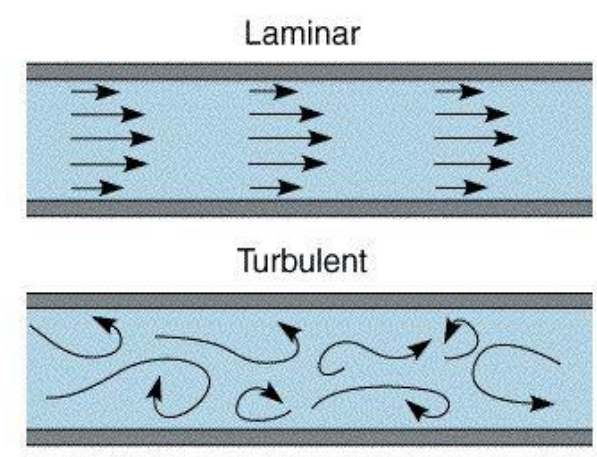

Gambar 1. Aliran laminar dan turbulen

\section{b. Aliran Darah Turbulen Pada Beberapa Keadaan}

Ketika kecepatan aliran darah menjadi terlalu besar, sewaktu melewati suatu obstruksi di pembuluh, sewaktu aliran berbelok tajam, atau sewaktu mengalir melalui permukaan kasar, aliran dapat menjadi turbulen dan tidak laminar. Aliran turbulen berarti bahwa darah mengalir melintang di pembuluh maupun sepanjang pembuluh, biasanya membentuk pusaran dalam darah yang disebut aliran eddy. Ini serupa dengan pusaran air yang sering kita lihat di sungai beraliran cepat pada tempat adanya hambatan.

Bila terdapat aliran eddy, darah mengalir dengan tahanan yang jauh lebih besar daripada bila mengalir laminar karena aliran eddy menambah besar seluruh gesekan aliran dalam pembuluh. ${ }^{(2,3)}$

Kecenderungan untuk timbulnya aliran turbulen meningkat sebanding dengan kecepatan aliran darah, sebanding dengan diameter pembuluh darah, dan berbanding terbalik dengan viskositas darah, dibagi berat jenisnya sesuai dengan persamaan berikut. ${ }^{(5,6)}$ 


$$
\operatorname{Re}=\frac{v \cdot d}{\frac{\eta}{\rho}}
$$

dimana:

$\operatorname{Re} \quad=$ bilangan Reynold merupakan ukuran kecenderungan terjadinya turbulensi

$\mathrm{V} \quad=$ kecepatan aliran darah (dalam sentimeter per detik)

$\mathrm{d}=$ diameter

$\eta \quad=$ viskositas

$\rho \quad=$ berat jenis

Bila bilangan Reynold meningkat di atas 2000, biasanya timbul turbulensi bahkan di pembuluh yang lurus dan halus.Bilangan Reynold sangat sering meningkat sampai 2000 di beberapa arteri besar; akibatnya hampir selalu terdapat sedikit aliran turbulen di beberapa arteri, seperti pada ujung aorta dan pada cabang arteri utama. ${ }^{(7)}$
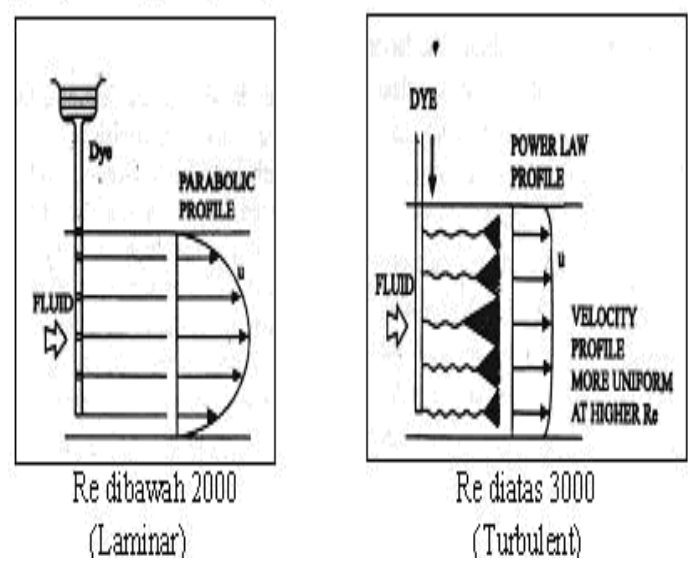

Re diatas 3000

(Tưoulent)

Gambar 2. Skema aliran laminar dan turbulen $^{(9)}$

Aliran darah pada orang dewasa saat istirahat adalah $5 \mathrm{~L} /$ menit, yang disebut sebagai curah jantung (cardiac output). Aliran darah melalui pembuluh darah dipengaruhi oleh dua faktor:

1. Perbedaan Tekanan (DP: P1-P2), merupakan penyebab terdorongnya darah melalui pembuluh.
2. Hambatan terhadap aliran darah sepanjang pembuluh, disebut juga sebagai "vascular resistance" atau tahanan pembuluh.

Beda tekanan antara dua ujung pembuluh darah menyebabkan darah mengalir dari daerah bertekanan tinggi ke daerah bertekanan rendah, sedangkan resistensi/tahanan menghambat aliran darah.

Rumus : $\mathrm{Q}: \frac{\mathrm{DP}}{\mathrm{R}}$

Q : aliran

DP : perbedaan tekanan

$\mathrm{R} \quad$ : resistensi

\section{Resistensi}

Resistensi/tahanan adalah hambatan terhadap aliran darah terhadap suatu pembuluh yang tidak dapat diukur secara langsung. Resistensi dipengaruhi oleh dua faktor yaitu: diameter pembuluh darah (terutama arteriol) dan viskositas (kekentalan) darah. Peningkatan diameter pembuluh darah (vasodilatasi) akan menurunkan tahanan, sedangkan penurunan diameter pembuluh darah (vasokontriksi) dapat meningkatkan resistensi. Viskositas sebagian besar dipengaruhi oleh kadar hematokrit (ht), yaitu prosentase volume darah yang ditempati oleh sel darah merah. Semakin tinggi viskositas darah, maka semakin meningkat pula resistensi pembuluh darah. ${ }^{(2)}$

\section{Viskositas Darah}

Fluida, baik zat cair maupun zat gas yang jenisnya berbeda memiliki tingkat kekentalan yang berbeda. Viskositas atau kekentalan $(\eta)$ sebenarnya merupakan gaya gesekan internal antara molekul-molekul dan partikelpartikel yang menyusun suatu fluida dalam pembuluh darah yang berbentuk silinder. Kalau diperhatikan silinder (aliran laminer) pembuluh darah pada gambar 3 dapat diilustrasikan gesekan 
dalam fluida ini. Pada zat cair, fluida (dv) dibagi jarak terjadinya viskositas disebabkan karena adanya perubahan $(\mathrm{dx})$ atau disebut juga gaya kohesi (gaya tarik menarik antara dengan shear rate $(\mathrm{dv} / \mathrm{dx})$.

molekul sejenis). Sedangkan dalam zat gas, viskositas disebabkan oleh tumbukan antara molekul. ${ }^{(3,8)}$

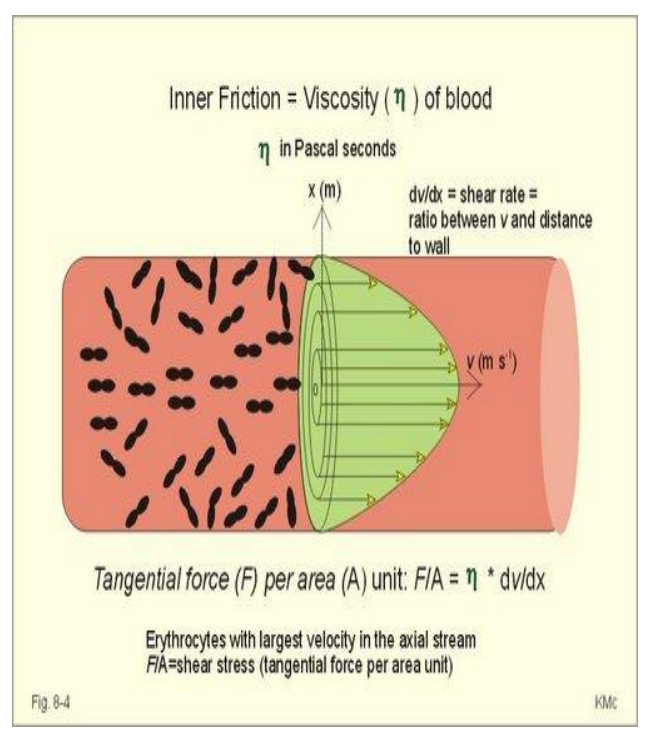

Gambar 3. Pembuluh darah dengan sel darah dan tanda panah menunjukkan kecepatan (v) yang berbeda

Lapisan paling luar silinder dalam keadaan diam, mulai dari dinding pembuluh (kecepatan nol), bagian sentral silinder bergerak dengan (aliran laminer) dengan kecepatan yang sangat cepat, sedangkan lapisan yang berada dibawahnya bergerak dengan kecepatan yang lebih kecil, demikian seterusnya. Bentuk kecepatan ini adalah berbentuk Parabolic. Jarak (x) dari lapisan tengah pembuluh darah sampai ke lapisan paling luar silinder. Gradien kecepatan adalah, perubahan kecepatan lapisan
Bagian yang menempel pada dinding pembuluh/silinder bisa bergerak karena ada gaya tarik (F). Besarnya gaya tarik yang dibutuhkan berbanding lurus dengan luas bagian yang menempel (A), kecepatan (dv) dan berbanding terbalik dengan jarak $d x$. Secara matematis, bisa ditulis sebagai berikut :

$$
\mathrm{F} \sim \frac{\mathrm{Adv}}{\mathrm{dx}}
$$

Tingkat kekentalan fluida dinyatakan dengan koofisien viskositas. Jika fluida makin kental maka gaya tarik yang dibutuhkan juga makin besar. Dalam hal ini, gaya tarik berbanding lurus dengan koofisien kekentalan. Secara matematis bisa ditulis sebagai berikut :

$$
\mathrm{F} \sim \eta
$$

Sehingga kita dapatkan:

$$
\mathrm{F}=\eta \frac{\mathrm{Adv}}{\mathrm{dx}} \quad \eta=\frac{\mathrm{Fdx}}{\mathrm{Adv}}
$$

Satuan Sistem Internasional (SI) untuk koofisien viskositas adalah $\mathrm{Ns} / \mathrm{m}^{2}=$ Pa.s (pascal sekon). Satuan CGS (centimeter gram sekon) untuk koefisien viskositas adalah dyn. $\mathrm{s} / \mathrm{cm}^{2}=$ poise $(\mathrm{P})$. Viskositas juga sering dinyatakan dalam sentipoise $(\mathrm{cP}) .1 \mathrm{cP}=$ 1/100 P. Satuan poise digunakan untuk mengenang seorang Ilmuwan Perancis, almahrum Jean Louis Marie Poiseuille 1 poise $=1$ dyn. $\mathrm{s} / \mathrm{cm}^{2}=10^{-1} \mathrm{~N} . \mathrm{s} / \mathrm{m}^{2}$. 
Tabel. Koefisien Viskositas untuk berbagai Fluida ${ }^{(3)}$

\begin{tabular}{|c|c|c|}
\hline Fluida & $\begin{array}{l}\text { Temperatur } \\
\left({ }^{\circ} \mathrm{C}\right)\end{array}$ & $\begin{array}{l}\text { Koofisien } \\
\text { Viskositas, } \\
\eta(\text { Pa.s) }\end{array}$ \\
\hline Air & $\begin{array}{l}0 \\
20 \\
60 \\
100\end{array}$ & $\begin{array}{l}1,8 \times 10^{-3} \\
1,0 \times 10^{-3} \\
0,65 \times 10^{-3} \\
0,3 \times 10^{-3}\end{array}$ \\
\hline $\begin{array}{l}\text { Darah } \\
\text { (keseluruha } \\
\text { n) }\end{array}$ & 37 & $4,0 \times 10^{-3}$ \\
\hline $\begin{array}{l}\text { Plasma } \\
\text { Darah }\end{array}$ & 37 & $1,5 \times 10^{-3}$ \\
\hline $\begin{array}{l}\text { Ethyl } \\
\text { alkohol }\end{array}$ & 20 & $1,2 \times 10^{-3}$ \\
\hline $\begin{array}{l}\text { Oli mesin } \\
\text { (SAE } 10)\end{array}$ & & $200 \times 10^{-3}$ \\
\hline Gliserin & $\begin{array}{l}0 \\
20 \\
60\end{array}$ & $\begin{array}{l}10.000 \times 10^{-3} \\
1500 \times 10^{-3} \\
81 \times 10^{-3}\end{array}$ \\
\hline Udara & 20 & $0,018 \times 10^{-3}$ \\
\hline Hidrogen & 0 & $0,009 \times 10^{-3}$ \\
\hline Uap air & 100 & $0,013 \times 10^{-3}$ \\
\hline
\end{tabular}

\section{Hukum Poiseuille}

Laju aliran darah melalui tubuh secara umum berbentuk laminar dari pada turbulen. Oleh karena itu kita dapat memperlakukan aliran darah di dalam arteri identik ketika suatu cairan bergerak secara laminar dalam suatu pipa kecil. Karena gaya molekular yang atraktif antara darah dengan dinding dalam dari arteri maka tidak ada aliran darah yang berkontak langsung dengan dinding arteri. (hal ini juga untuk aliran fluid di dalam pipa). ${ }^{(9)}$

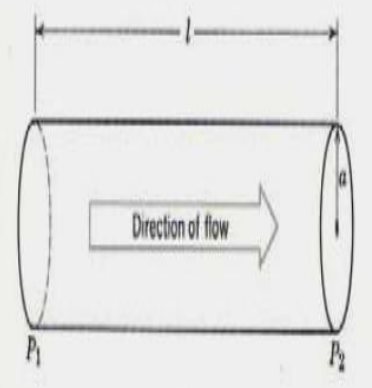

(a)

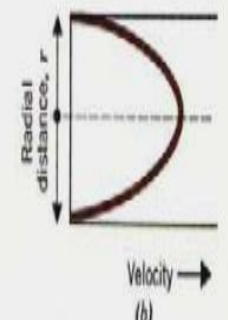

(b)
Gambar 4a. Cairan viskous yang mengalir melalui pipa halus memiliki distribusi kecepatan parabolik

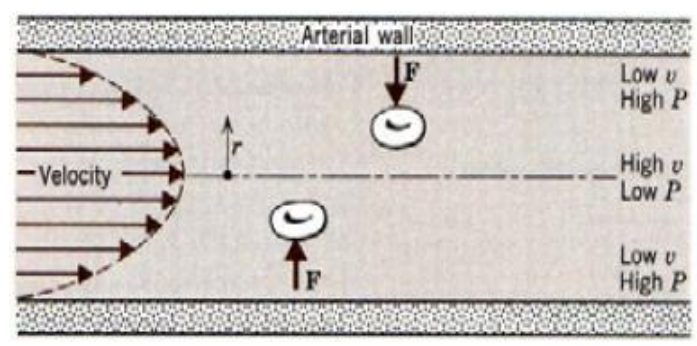

Gambar 4b. variasi kecepatan melewati diameter dari arteri disertai dengan variasi yang menekan sel darah ke arah tengah dari arteri

Akibatnya kecepatan aliran darah adalah nol pada dinding arteri dan aliran lebih cepat di tengah dari arteri. Adalah memungkinkan untuk mendapatkan bentuk kecepatan aliran fluida (menggunakan metode kalkulus) sebagai fungsi dari jarak $\mathrm{r}$ dari tengah pipa. Seperti yang ditunjukkan dari gambar 4a., kita berasumsi bahwa radius dalam a dan panjang 1 dimana perbedaan kecepatan P1-P2. Jika viskositas dalam fluida adalah $\eta$ maka kecepatan adalah :

$$
\mathrm{V}=\frac{1}{4 \eta l}(P 1-P 2)\left(a^{2}-r^{2}\right)
$$

Gambar 4.b. menunjukkan bagaiman kecepatan bervariasi terhadap diameter pipa

Perhatikan bahwa bentuk dari kurva kecepatan adalah parabolik.

Karena aliran kecepatan berubah dengan jarak radial tabung dari arteri maka dari persamaan Poiseuille menunjukkan bahwa harus terdapat perubahan tekanan dalam tabung. Kecepatan yang rendah dekat dengan dinding menunjukkan adanya tekanan yang lebih tinggi. Pada tengah tabung dimana 
kecepatan lebih besar, tekanan relative lebih kecil. Maka tekanan meningkat ketika jarak radial meningkat. Berbagai objek kecil seperti sel darah merah mengalir melalui tabung selanjutnya akan mengalami perbedaan tekanan radial. Perbedaan tekanan menghasilkan gaya yang cenderung untuk menekan sel darah kearah tengah pada tabung. Seperti yang ditunjukan pada gambar 4.b. Kita mengetahui dari bukti lain bahwa sel darah terkonsentrasi di tengah tabung arteri.

Kita dapat menggunakan persaman di atas untuk kecepatan (dengan metode kalkulus) untuk menghitung laju aliran darah fluida melalui pipa. Laju aliran (flow rate) Q (F) diukur dalam $\mathrm{m} 3 / \mathrm{s}$ diberikan :
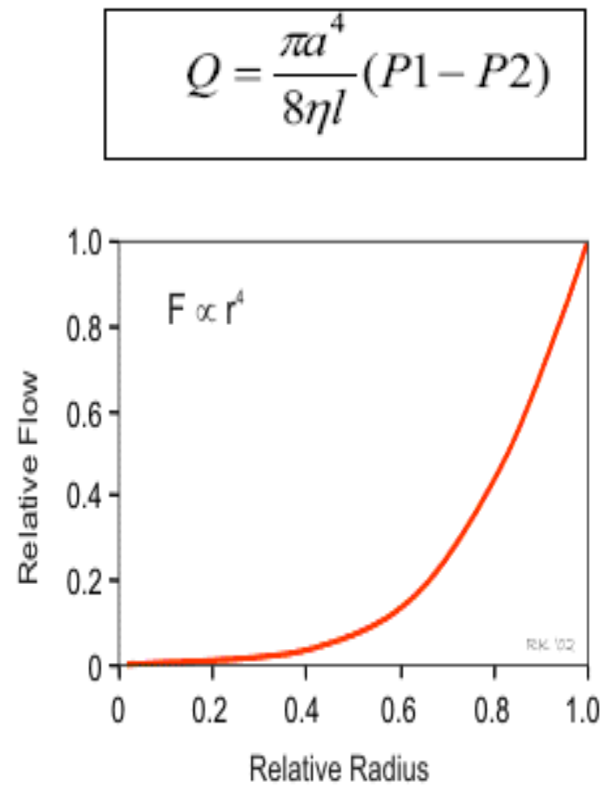

Gambar 5. Hubungan antara aliran darah dan radius pembuluh ${ }^{(10)}$

Persamaan di atas dikenal sebagai persamaan Poiseuille's, setelah Fisiologis francis Jean Marie Poiseuille (17991869) yang pertama kali merumuskannya. Perhatikan bahwa Q(F) ber- gantung pada radius a; ketika a meningkat dua kali lipat $\mathrm{Q}$ meningkat dengan pangkat 16. Demikian juga ketika a dibuat lebih kecil, kecepatan aliran menurun secara drastis. Jika dalam beberapa kondisi sebagai akibat dari adanya penebalan dinding arteri (yang memberi efek menjadi semakin lebih kecil), menurunnya kecepatan aliran darah dapat menyebabkan angina pectoris, ditandai dengan rasa sakit dada ketika aktivitas fisik. Penyebab tersering terjadinya angina pectoris adalah arteriosclerosis, adanya penebalan dari arteri. Menghilangkan rasa sakit dapat digunakan beberapa obat seperti nitroglycerine yang dapat melemaskan otot dinding arteri dan jari-jari a menjadi lebih besar, sehingga terjadi laju aliran darah dan menurunkan beban jantung. ${ }^{(10-12)}$

\section{FAKTOR - FAKTOR YANG MEMPENGARUHI VISKOSITAS DARAH}

Viskositas darah memegang peranan penting dalam aliran darah. Faktorfaktor yang mempengaruhi viskositas darah antara lain :

\section{HEMATOKRIT (sel darah merah)}

Semakin besar persentase sel dalam darah, artinya semakin besar hematokrit semakin banyak gesekan yang terjadi antara berbagai lapisan darah, dan gesekan ini menentukan viskositas. Karena itu, viskositas darah meningkat hebat dengan meningkatnya hematokrit, seperti terlihat pada gambar 6. Bila kita menganggap viskositas darah lengkap pada hematokrit normal adalah sekitar 3, ini berarti bahwa diperlukan tekanan 3 kali lebih besar untuk mendorong darah seperti mendorong air melalui tabung yang sama. 


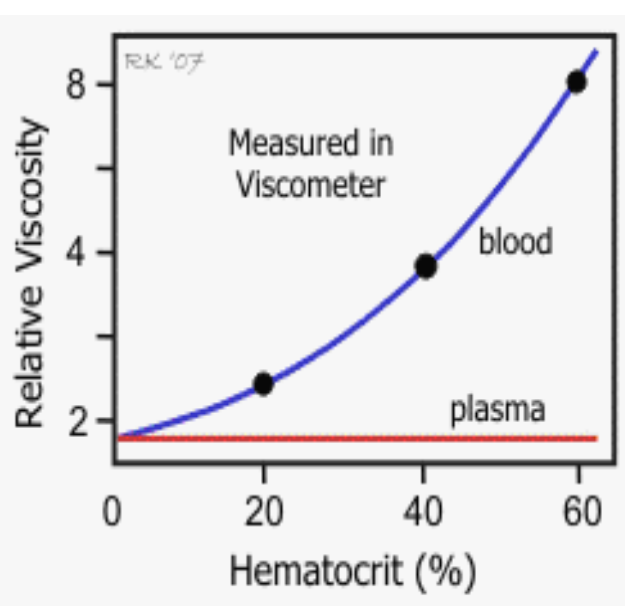

Gambar 6. Efek hematokrit terhadap viskositas ${ }^{(10)}$

Seperti yang ditunjukkan pada gambar di mana viskositas darah keseluruhan ditentukan secara in vitro menggunakan viskometer, di mana peningkatan hematokrit sel darah merah menyebabkan peningkatan viskositas relatif. Perhatikan bahwa peningkatan ini non-linear, sehingga hematokrit lebih dari dua kali lipat ganda viskositas relatif. Oleh karena itu, viskositas darah sangat tergantung pada hematokrit. Pada hematokrit normal $40-45 \%$, relatif viskositas darah 4-5 mPa.s. Bila hematokrit meningkat sampai 60 atau 70 , yang sering terjadi pada polisitemia, kapasitas transport oksigen lebih besar, viskositas darah menjadi 10 kali lebih besar dari pada air, dapat berkembang menjadi thrombosis dan emboli. Hal ini meningkatkan resistensi terhadap aliran darah sehingga meningkatkan kerja jantung dan dapat mengganggu perfusi organ. Pasien dengan anemia mempunyai hematokrit $30 \%$, mempunyai viskositas darah rendah dan kapasitas transport oksigen yang sedikit. ${ }^{(2,8)}$

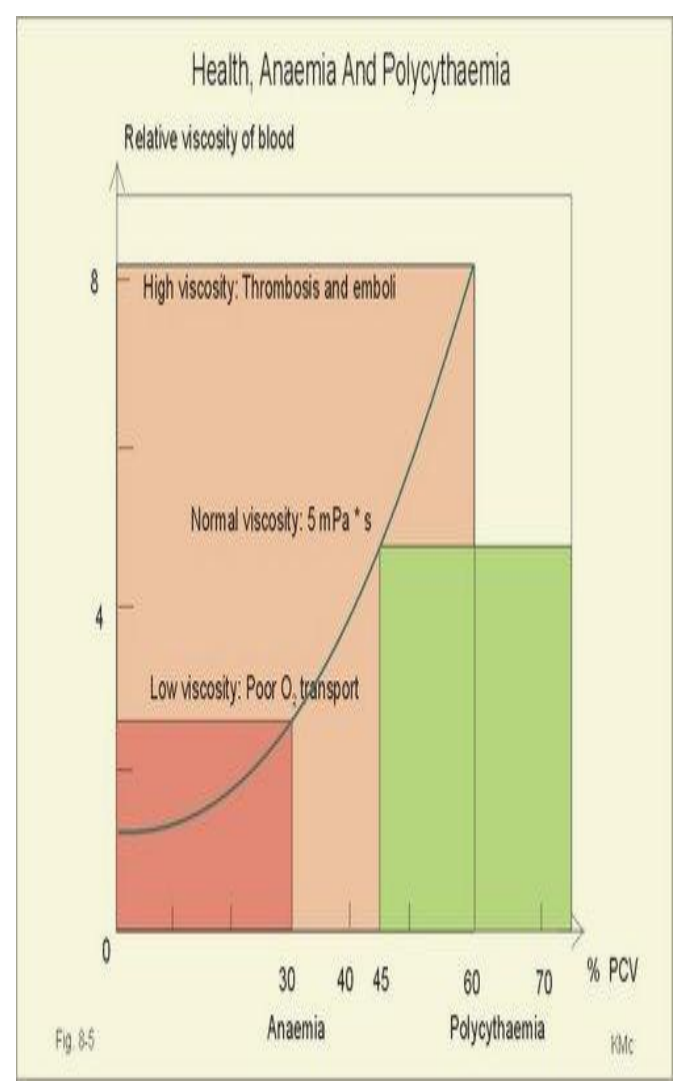

Gambar 7. Viskositas darah tergantung pada konsentrasi sel darah (hematokrit/PCV)

\section{SUHU TUBUH}

Ketika darah menjadi dingin, darah akan mengalir lebih lambat. Oleh karena itu, ada hubungan terbalik antara suhu dan viskositas. Viskositas meningkat sekitar 2\% untuk setiap penurunan suhu derajat Celcius. Biasanya, suhu darah tidak berubah banyak dalam tubuh. Namun, jika tangan seseorang terkena lingkungan yang dingin dan jari-jari menjadi dingin, suhu darah di jari akan turun dan meningkatkan viskositas, yang bersama-sama dengan vasokonstriksi simpatik-dimediasi akan mengurangi aliran darah di daerah dingin. Pada hipotermia pada perawatan 
kritis atau situasi bedah, ini juga akan menyebabkan peningkatan viskositas darah sehingga mempengaruhi hemodinamik sistemik dan organ aliran darah. $^{(10)}$

\section{KADAR PROTEIN PLASMA}

Bila kadarnya naik maka viskositas akan naik dan sebaliknya. Pengaruhnya kurang begitu penting dibandingkan dengan pengaruh hematokrit, sehingga tidak dipertimbangkan secara serius dalam penelitian hemodinamik. Viskositas plasma darah adalah sekitar 1.5 kali air. ${ }^{(2)}$

\section{KECEPATAN ALIRAN DARAH}

Sebagai gambaran air, gas dan fluida homogen lainnya adalah fluida Newtonian dimasukkan sebagai fluida yang viskositasnya tidak tergantung pada kecepatan aliran. Fluida Newtonian bergerak streamline atau aliran laminar.

Viskositas dari non fluida Newtonian berkurang dengan meningkatnya kecepatan aliran. Darah adalah tidak homogen dengan viskositasnya tergantung pada kecepatan aliran. Viskositas darah meningkat hebat dengan menurunnya kecepatan aliran. Karena kecepatan aliran darah dipembuluh kecil sangat rendah, seringkali kurang dari 1 $\mathrm{mm}$ /detik, viskositas darah dapat meningkat sebanyak 10 kali lipat dari factor itu sendiri. Efek ini sebagian disebabkan oleh perlekatan antara selsel darah merah yang bergerak lambat satu dengan yang lainnya (pembentukan rouleaux dan kumpulan yang lebih besar) atau dengan dinding pembuluh. $^{(10)}$

\section{DIAMETER PEMBULUH DARAH}

Karena sebagian besar tahanan dalam sistem sirkulasi terjadi di pembuluh darah yang sangat kecil, maka penting untuk mengetahui bagaimana viskositas darah mempengaruhi aliran darah dalam pembuluh darah kecil. a. Aliran darah dalam pembuluh kecil memperlihatkan jauh lebih sedikit efek viskus dari pada di pembuluh besar. Efek ini disebut efek FahraeusLindqvist. Hal ini mulai muncul bila diameter pembuluh turun dibawah sekitar 1,5 melimeter. Pada pembuluh sekitar kapiler, viskositas darah lengkap menurun menjadi setengah dari yang ada di pembuluh besar. Efek FahraeusLindqvist disebabkan oleh pengelompokan sel darah merah sewaktu melalui pembuluh. Artinya sel-sel darah merah, yang biasanya bergerak secara acak, sekarang berjajar dan bergerak melalui pembuluh sebagai kelompok tunggal, sehingga menghilangkan tahanan viskus yang timbul secara internal dalam pembuluh itu sendiri. ${ }^{(2,8,10)}$

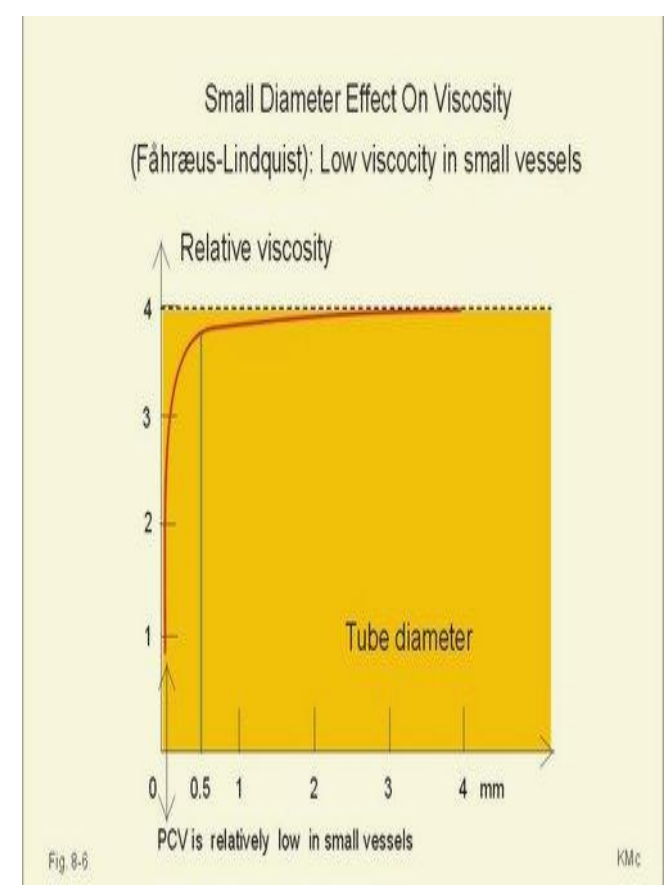

Gambar 8. Viskositas darah menurun dalam pembuluh yang berdiameter kecil dari 0,5 mm (Efek Fahraeus-Lindqvist)

b. Sel-sel sering kali tertumpuk pada tempat konstriksi di pembuluh darah kecil, hal ini terutama terjadi dikapiler tempat nukleus sel-sel endotel menonjol 
ke dalam lumen kapiler. Bila hal ini terjadi, aliran darah dapat menjadi terhambat selama seperbeberapa detik atau lebih lama, sehingga memperlihatkan efek kenaikan viskositas yang luar biasa.

Akibat efek-efek khusus yang terjadi di pembuluh kecil sistem sirkulasi ini, tidak mungkin mendapatkan suatu hubungan matematik yang pasti tentang bagaimana hematokrit mempengaruhi viskositas di pembuluh kecil, yang merupakan tempat di sistem sirkulasi dimana viskositas berperan sangat penting. Karena beberapa dari pengaruh ini menurunkan viskositas dan lainnya meningkatkan viskositas, maka biasanya dianggap bahwa seluruh pengaruh viskus di pembuluh kecil kira-kira sama dengan yang timbul di pembuluh besar. $^{(2)}$

\section{KESIMPULAN}

1. Viskositas atau kekentalan ( $\eta$ ) sebenarnya merupakan gaya gesekan internal antara molekulmolekul dan partikel-partikel yang menyusun suatu fluida dalam pembuluh darah yang berbentuk silinder.

2. Aplikasi Hukum Poiseuille sebagai akibat penebalan dinding arteri, menurunnya kecepatan aliran darah dapat menyebabkan angina pectoris, Penyebab tersering adalah arteriosclerosis.

3. Viskositas darah normal 4-5 kali viskositas air. Viskositas plasma darah 1,5 kali viskositas air.

4. Faktor-faktor yang mempengaruhi viskositas darah :

a) Hematokrit : hematokrit yang meningkat akan diikuti viskositas darah yang meningkat.

b) Suhu tubuh: bila suhu tubuh naik, viskositas turun.

c) Kadar protein plasma: bila kadarnya naik maka viskositas naik dan sebaliknya.

d) Kecepatan aliran darah: bila kecepatan aliran darah turun maka viskositas naik.

e) Diameter pembuluh darah: bila diameter pembuluh darah kurang dari 1,5 mm, maka efek viskus jauh lebih sedikit

\section{KEPUSTAKAAN}

1. Wijaya AM. Sistem Sirkulasi Darah Dalam Tubuh Manusia. Info Kesehatan, 2009.

2. Guyton AC, Hall JE. Buku Ajar Fisiologi Kedokteran. editor bahasa Indonesia: Irawati Setiawan Ed. 9 Jakarta: EGC,1997.

3. Giancoli DC. Fisika .Jilid I (terjemahan), Ed 5, Jakarta, Penerbit Erlangga, 2001, h. 347350.

4. Cameron JR, Skofronick JG, Grant RM. Fisika Tubuh Manusia. Ed. 2, Jakarta: Penerbit EGC, 2006. h. 219-220.

5. 5.Fouiz, Infaz. Fluid Mechanics. Mechanical Engineering Dept, Umiversity of Oxford, 2001.

6. Jermy M. Fluid Mechanics A Course Reader, Mechanichal Engineering Dept, University of Canterbury, Written at hlm. d 5.10, 2005.

7. Versteeg HK, Malalasekera W. An Introduction to Computational Fluid Dynamics. John wlley and Sons Inc. 1995.

8. "http://www.pharmpedia.com/Phys iology And Pathophysiology text 
book/Cardiovascular physiology and disorders",September 2007.

9. Franco G. Applications of Poiseuille's Law To Vascular Accesses. Controversies \& Updates in Vascular Surgery, 2009 January $30-31$.

10. Klabunde RE. Hemodynamics (Pressure, Flow, and Resistance), Viscosity of Blood. Cardiovascular Physiology Consepts, a text book published by Lippincott Williams \& Wilkins, 2005.
11. Widjaja D. Hipertensi dan Stroke. Cermin Dunia Kedokteran, 1994 No. 95.

12. Puruhito. Terapi Hemorheologi. Dexa Media, 2007 no.2, vol.20, April - Juni. 